\title{
PENAFSIRAN HUKUM KOMISI PEMILIHAN UMUM TERHADAP PEMBATALAN CALON KEPALA DAERAH DAN WAKIL KEPALA DAERAH
}

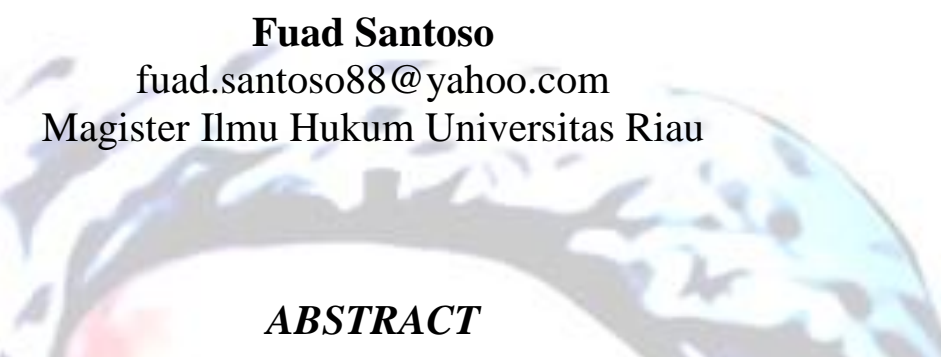

Aceh Tamiang Independent Election Commission interprets the Health Examination Team is authorized to declare candidates for election to fulfill the requirements or not fulfill the requirements to become election participants. Whereas according to the interpretation of the Supreme Court, the team only has the authority to state whether or not there is a disability and the extent to which the disability does not state that the candidates for election are eligible or do not meet the requirements to become Pilkada participants. The General Election Commission of Pekanbaru City interpreted people with disabilities to be prevented from obtaining political rights. Meanwhile, according to the Pekanbaru Election Supervisory Committee, people with disabilities are not hindered from obtaining political rights. The ideal legal regulation for the cancellation of candidates for regional heads and deputy regional heads who do not meet the health requirements by the Election Commission is: The legislator expressly states that the Health Examination Team is only authorized to state whether or not there is a disability.

Keywords: Regional Head Election, Disability, Political Rights

\begin{abstract}
ABSTRAK
Komisi Independen Pemilihan Aceh Tamiang menafsirkan Tim Pemeriksa Kesehatan berwenang untuk menyatakan calon peserta Pilkada memenuhi syarat atau tidak memenuhi syarat menjadi peserta Pilkada. Sedangkan menurut tafsiran Mahkamah Agung, tim tersebut hanya berwenang menyatakan ada atau tidaknya disabilitas serta sejauh mana disabilitas tersebut, bukan menyatakan calon peserta Pilkada memenuhi syarat atau tidak memenuhi syarat menjadi peserta Pilkada. Komisi Pemilihan Umum Kota Pekanbaru menafsirkan penyandang disabilitas terhalang untuk mendapatkan hak politik. Sedangkan menurut Panitia Pengawas Pemilihan Kota Pekanbaru, penyandang disabilitas tidak terhalang untuk mendapatkan hak politik. Pengaturan hukum yang ideal terhadap pembatalan calon kepala daerah dan wakil kepala daerah yang tidak memenuhi persyaratan kesehatan oleh KPUD adalah: Pembentuk undang-undang tegas menyatakan bahwa Tim Pemeriksa Kesehatan hanya berwenang menyatakan ada atau tidaknya disabilitas.
\end{abstract}

Kata Kunci: Pemilihan Kepala Daerah, Disabilitas, Hak Politik 


\section{PENDAHULUAN}

Berdasarkan Pasal 18 ayat (4) Undang-Undang Dasar Negara Republik Indonesia Tahun 1945, Gubernur, Bupati, dan Walikota masing-masing sebagai kepala pemerintah daerah provinsi, kabupaten, dan kota dipilih secara demokratis. ${ }^{1}$ Menurut Mahfud MD, salah satu ciri konfigurasi politik negara yang konfigurasi politiknya demokratis adalah kesempatan bagi partisipasi rakyat secara penuh ikut aktif menentukan kebijakan umum, dan terdapat kebebasan bagi rakyat melalui wakil-wakilnya untuk melancarkan kritik terhadap pemerintah. ${ }^{2}$

Setiap warga negara berhak memperoleh kesempatan yang sama untuk mencalonkan diri dan dicalonkan sebagai Calon Gubernur dan Calon Wakil Gubernur, Calon Bupati dan Calon Wakil Bupati, serta Calon Walikota dan Calon Wakil Walikota. ${ }^{3}$ Calon tersebut harus

\footnotetext{
${ }^{1}$ Penjelasan Umum atas Undang-Undang Nomor 10 Tahun 2016 tentang Perubahan Kedua atas Undang-Undang Nomor 1 Tahun 2015 tentang Penetapan Peraturan Pemerintah Pengganti Undang-Undang Nomor 1 Tahun 2014 tentang Pemilihan Gubernur, Bupati, dan Walikota Menjadi Undang-Undang.

2 Dessy Artina. 2016. Keterwakilan Politik Perempuan di Beberapa Negara, Yogyakarta: Best Publisher, h. 37.

${ }^{3}$ Pasal 7 ayat (1) Undang-Undang Nomor 10 Tahun 2016 tentang Perubahan Kedua atas Undang-Undang Nomor 1 Tahun 2015 tentang Penetapan Peraturan Pemerintah Pengganti Undang-Undang Nomor 1 Tahun 2014 tentang Pemilihan Gubernur, Bupati, dan Walikota Menjadi Undang-Undang.
}

memenuhi beberapa persyaratan. Salah satu dari persyaratan tersebut adalah mampu secara jasmani, rohani, dan bebas dari - penyalahgunaan narkotika berdasarkan hasil pemeriksaan kesehatan menyeluruh dari tim. ${ }^{4}$

\section{Persyaratan-persyaratan yang}

sudah diuraikan sebelumnya menurut penulis tidak terlepas dari keinginan pembentuk undang-undang bahwa setiap daerah harus memiliki pemimpin (Gubernur, Bupati, dan Walikota) yang mampu bekerja semaksimal mungkin untuk kepentingan daerah dan kepentingan masyarakat di daerah pada khususnya dan untuk kepentingan negara pada umumnya. Hal ini menurut Josef Riwu Kaho, ${ }^{5}$ disebabkan manajemen pemerintahan daerah yang baik tergantung pada kepala daerah (beserta stafnya) dalam menggerakkan peralatan seefisien dan seefektif mungkin untuk mencapai tujuan yang telah ditetapkan dalam undang-undang.

\footnotetext{
4 Pasal 7 ayat (2) Undang-Undang Nomor 10 Tahun 2016 tentang Perubahan Kedua atas Undang-Undang Nomor 1 Tahun 2015 tentang Penetapan Peraturan Pemerintah Pengganti Undang-Undang Nomor 1 Tahun 2014 tentang Pemilihan Gubernur, Bupati, dan Walikota Menjadi Undang-Undang.

5 Josef Riwu Kaho. 2010/ Prospek Otonomi Daerah di Negara Republik Indonesia (Identifikasi Faktor-faktor yang Mempengaruhi Penyelenggaraan Otonomi Daerah), Jakarta: Rajawali Pers, hlm. 70.
} 
Model pemilihan Kepala daerah di Indonesia pada saat ini adalah dipilih secara langsung oleh rakyat sebagaimana dikembangkan dalam model negara yang menganut sistem pemerintah presidensial. $^{6}$

Menurut Rozali Abdullah, terdapat tiga alasan terhadap pentingnya pemilihan Kepala daerah yang dipilih secara langsung. Ketiga alasan tersebut adalah mengembalikan kedaulatan ke tangan rakyat, legitimasi yang sama antara Kepala Daerah dan Wakil Kepala Daerah dengan DPRD, dan kedudukan yang sejajar antara Kepala Daerah dan Wakil Kepala Daerah dengan DPRD. ${ }^{7}$ Seperti halnya presiden dan waki presiden, kepala daerah dan wakil kepala daerah di samping merupakan dua organ jabatan yang dapat dibedakan, juga merupakan satu kesatuan institusi kepala daerah. ${ }^{8}$

Kembali pada persoalan setiap warga negara berhak memperoleh kesempatan yang sama untuk mencalonkan diri dan dicalonkan sebagai

${ }^{6}$ Faisal Akbar Nasution. 2009. Pemerintahan Daerah dan Sumber-sumber Pendapatan Asli Daerah, Jakarta: Sofmedia, hlm. 114.

7 Rozali Abdullah. 2011. Pelaksanaan Otonomi Luas dengan Pemilihan Kepala Daerah Secara Langsung, Jakarta: RajaGrafindo Persada, hlm. 53-54.

8 Jimly Asshiddiqie. 2010. Perkembangan \& Konsolidasi Lembaga Negara Pasca Reformasi, Jakarta: Sinar Grafika, hlm. 110.
Calon Gubernur dan Calon Wakil Gubernur, Calon Bupati dan Calon Wakil Bupati, serta Calon Walikota dan Calon Wakil Walikota, fakta membuktikan bahwa hak tersebut tidak serta merta bisa diperoleh karena warga negara yang mencalonkan diri harus memenuhi persyaratan-persyaratan tertentu yang sudah ditetapkan oleh undang-undang, di antaranya adalah persyaratan mengenai kesehatan. Selain itu, fakta hukum juga membuktikan tidak dapat dielakkan terjadinya sengketa dalam hal penetapan seorang warga negara menjadi calon kepala daerah yang disebabkan oleh persyaratan kesehatan dari calon kepala daerah.

Faktor utama terjadinya sengketa tersebut adalah calon kepala daerah dan wakil kepala daerah dinyatakan tidak lulus dalam tes kesehatan oleh penyelenggara Pemilukada. Penyelenggara Pemilukada tersebut adalah Komisi Pemilihan Umum Daerah (KPUD) atau Komisi Independen Pemilihan (KIP). Perlu ditegaskan di sini bahwa KIP hanya berada di Aceh. Dengan demikian, yang menjadi objek sengketa dalam hal tersebut adalah terbitnya Keputusan KPUD atau Keputusan KIP tentang Penetapan Pasangan Calon Peserta Pemilihan 
Kepala Daerah yang tidak menetapkan calon sebagai pasangan calon kepala daerah.

Beberapa sengketa terhadap calon kepala daerah dan wakil kepala daerah dinyatakan tidak lulus dalam tes kesehatan oleh penyelenggara Pemilukada adalah sebagaimana yang telah diputus oleh Mahkamah Agung dalam perkara Nomor 572 K/TUN/PILKADA/2016, dan sebagaimana yang telah diputus oleh Panitia Pengawas (Panwas) Pemilihan Kota Pekanbaru. Uraian singkat dari kedua sengketa tersebut, diuraikan sebagai berikut:

1. Penyelesaian Sengketa Pilkada berdasarkan Putusan Mahkamah Agung Nomor $\quad 572$ K/TUN/PILKADA/2016

Majelis hakim mengadili perkara ini dengan menyatakan:

a. Mengabulkan gugatan Penggugat untuk seluruhnya;

b. Menyatakan batal Keputusan Komisi Independen Pemilihan (KIP) Kabupaten Aceh Tamiang Nomor: $\quad$ 130/Kpts/KIP-Kab001.434600/2016, tanggal 24 Oktober 2016, tentang Penetapan Pasangan Calon Peserta Pemilihan Bupati dan Wakil Bupati Aceh
Tamiang Tahun 2017, khususnya Lampiran II;

c. Mewajibkan Tergugat untuk mencabut Keputusan KIP Kabupaten Aceh Tamiang Nomor: 130/Kpts/KIP-Kab001.434600/2016, tanggal 24 Oktober 2016, tentang Penetapan Pasangan Calon Peserta Pemilihan Bupati dan Wakil Bupati Aceh Tamiang Tahun 2017, khususnya Lampiran II;

d. Mewajibkan Tergugat untuk menerbitkan keputusan tentang penetapan Penggugat sebagai Pasangan Calon Peserta Pemilihan Bupati dan Wakil Bupati Aceh Tamiang Tahun $2017 .{ }^{9}$

2. Penyelesaian Sengketa Pilkada berdasarkan Putusan Panitia Pengawas (Panwas) Pemilihan Kota Pekanbaru

Destrayani Bibra dan Said Usman Abdulah bisa bernafas lega setelah Panitia Pengawas (Panwas) Pemilihan Kota Pekanbaru mengabulkan sebahagian permohonan terkait gugatan sengketa administrasi persyaratan calon peserta Pemilihan Kepala Daerah (Pilkada) 2017. Pada sidang pembacaan putusan yang

9 Salinan Putusan Mahkamah Agung Nomor 572 K/TUN/PILKADA/2016, hlm. 19. 
digelar di Kantor Sekretariat Panwas Kota Pekanbaru pada Sabtu, 5 November 2016, menyatakan bahwa pasangan yang diusung partai PDI Perjuangan dan PPP itu berhak menjadi peserta pada Pilkada Pekanbaru tahun 2017. Melalui keputusan itu, Panwas juga menyatakan mencabut surat keputusan (SK) KPU Pekanbaru No 59/KPTS/KPU-Kota004.435265/X/2016 tentang

Penetapan Pasangan Calon Walikota dan Calon Wakil Walikota yang Telah Memenuhi Persyaratan Sebagai Calon Walikota dan Wakil Walikota Pekanbaru. Selain itu, juga memerintahkan kepada KPU Kota Pekanbaru untuk segera melaksanakan putusan tersebut. Sebelumnya, KPU Kota Pekanbaru menyatakan pasangan Destrayani Bibra dan Said Usman dinyatakan gugur karena tidak memenuhi syarat sebagai calon walikota dan wakil walikota. ${ }^{10}$

Dari uraian di atas, menarik dilakukan kajian mengenai pertimbangan penetapan kembali calon kepala daerah

10 Mohamad Yoenus, Panwaslu Pekanbaru Menangkan Gugatan Pasangan DestrayaniSaid Usman, http://www.tribunnews.com/ regional/2016/11/06/panwaslupekanbarumena ngkangugatanpasang andestrayanisaidusman, diakses tanggal 17 Januari 2018. yang sebelumnya dinyatakan tidak lulus atau dinyatakan gugur karena tidak memenuhi syarat kesehatan sebagai calon kepala daerah. Atau dengan kata lain, terjadi penafsiran yang berbeda dari para pihak yang memiliki kewenangan dalam hal tersebut. Ketertarikan tersebut dirangkum dengan judul penelitian: Penafsiran Hukum terhadap Pembatalan Calon Kepala Daerah dan Wakil Kepala Daerah yang Tidak Memenuhi Persyaratan Kesehatan oleh Komisi Pemilihan Umum Daerah.

Rumusan masalah dalam penelitian ini terdiri dari 2 (dua) bagian, yaitu sebagai berikut: Pertama, bagaimanakah penafsiran hukum terhadap pembatalan calon kepala daerah dan wakil kepala daerah yang tidak memenuhi persyaratan kesehatan oleh KPUD? Kedua, bagaimanakah pengaturan hukum yang ideal terhadap pembatalan calon kepala daerah dan wakil kepala daerah yang tidak memenuhi persyaratan kesehatan oleh KPUD?

Menurut, Taliziduhu Ndraha, pemilihan kepala daerah adalah salah satu peristiwa yang dapat dijadikan lapangan studi buat studi kasus dalam suatu penelitian. $^{11}$ Berdasarkan pendapat

11 Taliziduhu Ndraha. 2011. Kybernology: Ilmu Pemerintahan Baru 1, Jakarta: Rineka Cipta, hlm. 19. 
tersebut, diuraikan metode penelitian di dalam penelitian ini, yaitu sebagai berikut.

\section{METODE PENELITIAN}

Jenis penelitian ini adalah penelitian hukum normatif dengan fokus pembahasan terhadap pembatalan calon kepala daerah yang dinyatakan tidak lulus oleh KPU Kota Pekanbaru dan KIP Kabupaten Aceh Tamiang.

Sumber data dalam penelitian hukum normatif ini adalah data sekunder yang dibedakan menjadi 3 (tiga) bagian, yaitu:

a. Bahan Hukum Primer, yaitu bahan-bahan hukum yang mengikat, seperti peraturan perundang-undangan dan putusan pengadilan. Peraturan perundang-undangan tersebut di antaranya Undang-Undang

Dasar Negara Republik Indonesia Tahun 1945 dan Undang-Undang Nomor 10

Tahun 2016 tentang Perubahan

Kedua atas Undang-Undang

Nomor 1 Tahun 2015 tentang

Penetapan

Peraturan

Pemerintah Pengganti Undang-

Undang Nomor 1 Tahun 2014

tentang Pemilihan Gubernur,
Bupati, dan Walikota Menjadi Undang-Undang.

b. Bahan Hukum Sekunder, yaitu bahan hukum yang memberikan penjelasan bahan hukum primer, yaitu hasil-hasil penelitian, hasil karya ilmiah dari kalangan hukum, dan lainnya yang terkait dengan pemilihan gubernur, bupati, dan walikota.

c. Bahan Hukum Tertier, yaitu bahan hukum yang memberikan petunjuk atau penjelasan terhadap bahan hukum primer dan sekunder, seperti kamus bahasa Indonesia dan informasi yang diperoleh dari internet.

Teknik pengumpulan data menggunakan metode kajian kepustakaan, yaitu peneliti secara cermat dan tepat menemukan data yang relevan, baik yang terdapat dalam peraturan perundang-undangan maupun yang terdapat dalam literatur-literatur yang memiliki hubungan dengan permasalahan yang diteliti.

Dalam penelitian hukum normatif ini, data dianalisis secara kualitatif. Analisis kualitatif tersebut berarti data dianalisis dengan tidak menggunakan 
statistik atau matematika ataupun yang sejenisnya, namun cukup dengan menguraikan secara deskriptif dari data yang telah diperoleh. Penarikan kesimpulan dalam penelitian ini menggunakan metode berfikir deduktif, yaitu menarik suatu kesimpulan dari suatu pernyataan atau dalil yang bersifat umum menjadi suatu pernyataan atau kasus yang bersifat khusus.

\section{HASIL PENELITIAN}

\section{A. Penafsiran Hukum terhadap} Pembatalan Calon Kepala Daerah dan Wakil Kepala Daerah yang Tidak Memenuhi Persyaratan Kesehatan oleh KPUD

Metode penafsiran diperlukan karena peraturan perundang-undangan tidak seluruhnya dapat disusun dalam bentuk yang jelas dan tidak membuka penafsiran lagi. ${ }^{12}$ Kemandirian dan kebebasan menjadi asas penting dalam kekuasaan kehakiman dalam hal penemuan hukum dengan asas analogi dan penafsiran hukum. ${ }^{13}$

Pada tahun 2017, tepatnya pada tanggal 11 Januari 2017, majelis hakim

12 Martitah. 2013. Dari Negative Legislature, Mahkamah Konstitusi, ke Positive Legislature?, Jakarta: Konstitusi Pers, hlm. 85.

${ }^{13}$ Zainal Arifin Hoesein. 2013. Judicial Review di Mahkamah Agung Republik Indonesia: Tiga Dekade Pengujian Peraturan Perundangundangan, Jakarta: Rajawali Pers, hlm. 81. pada Mahkamah Agung memiliki tafsir hukum yang berbeda atas putusan Keputusan Komisi Independen Pemilihan (KIP) Aceh dalam lingkup Pembatalan Calon Kepala Daerah dan Wakil Kepala Daerah. Oleh karena itu, di bawah ini diuraikan penafsiran hukum terhadap pembatalan calon kepala daerah dan wakil kepala daerah yang dinyatakan tidak lulus oleh Komisi Independen Pemilihan (KIP) Aceh Tamiang. Setelah uraian tersebut, diuraikan tafsir hukum terhadap pembatalan calon kepala daerah dan wakil kepala daerah yang dinyatakan tidak lulus oleh Komisi Pemilihan Umum (KPU) Kota Pekanbaru.

B. Penafsiran Hukum terhadap Pembatalan Calon Kepala Daerah dan Wakil Kepala Daerah yang Dinyatakan Tidak Lulus oleh Komisi Independen Pemilihan (KIP) Aceh Tamiang

Lukmanul Hakim dan Abdul Manaf, keduanya Warga Negara Indonesia yang memiliki pekerjaan sebagai wiraswasta yang diwakili kuasanya, yaitu Mukhlis Mukhtar, Muzakar, dan Hendri Saputra, para Advokad pada Law Firm Mukhlis, Safar \& Partners, mengajukan kasasi kepada Mahkamah Agung karena telah dirugikan dalam kapasitasnya sebagai Pasangan 
Bakal Calon Bupati dan Wakil Bupati

Aceh Tamiang dari jalur Independen (Perseorangan), yang ditetapkan sebagai Pasangan Calon yang tidak memenuhi syarat sebagai Peserta Pemilihan Bupati dan Wakil Bupati Aceh Tamiang Tahun 2017 oleh KIP Aceh Tamiang, di dalam KIP Aceh Tamiang Nomor 130/KPTS/KIP-Kab-001.434600/ 2016 tentang Penetapan Pasangan Calon Peserta Pemilihan Bupati dan Wakil Bupati Aceh Tamiang Tahun 2017 tertanggal 24 Oktober $2016 .^{14}$

Apa yang diatur di dalam UndangUndang Nomor 11 Tahun 2006 tentang Pemerintahan Aceh, ${ }^{15}$ dan apa yang diatur di dalam Qanun Aceh Nomor 5 Tahun 2012 tentang Pemilihan Gubernur/Wakil Gubernur, Bupati/Wakil Bupati dan Walikota/Wakil Walikota, ${ }^{16}$ menurut penulis sama halnya dengan yang diatur pada Pasal 7 ayat (2) huruf f UndangUndang Nomor 10 Tahun 2016 tentang Perubahan Kedua atas Undang-Undang Nomor 1 Tahun 2015 tentang Penetapan Peraturan Pemerintah Pengganti UndangUndang Nomor 1 Tahun 2014 tentang

14 Putusan Mahkamah Agung Nomor 572 K/TUN/PILKADA/2016, hlm. 1-2.

15 Khususnya pada Pasal 67 ayat (2) huruf f Undang-Undang Nomor 11 Tahun 2006 tentang Pemerintahan Aceh.

${ }^{16}$ Khususnya pada Pasal 22 huruf h Qanun Aceh Nomor 5 Tahun 2012 tentang Pemilihan Gubernur/Wakil Gubernur, Bupati/Wakil Bupati dan Walikota/Wakil Walikota.
Pemilihan Gubernur, Bupati, dan Walikota Menjadi Undang-Undang, yang menegaskan bahwa Calon Gubernur dan Calon Wakil Gubernur, Calon Bupati dan Calon Wakil Bupati, serta Calon Walikota dan Calon Wakil Walikota, harus mampu secara jasmani, rohani, dan bebas dari penyalahgunaan narkotika berdasarkan hasil pemeriksaan kesehatan menyeluruh dari tim.

Terkait dengan Pasal 67 ayat (2) huruf f Undang-Undang Nomor 11 Tahun 2006 tentang Pemerintahan Aceh, Mahkamah Agung memiliki penafsiran yang dapat dilihat dari pertimbangan hukumnya, yaitu Tim Pemeriksa Kesehatan hanya berwenang menyatakan ada atau tidaknya disabilitas serta sejauh mana disabilitas tersebut, bukan menyatakan calon peserta Pilkada memenuhi syarat atau tidak memenuhi syarat menjadi peserta Pilkada.

Pada pertimbangan hukum yang lain, Mahkamah Agung dalam perkara ini menegaskan bahwa hasil pemeriksaan kesehatan memang bersifat final dan tidak dapat dilakukan pemeriksaan pembanding. Namun demikian, pemeriksaan dalam perkara ini tidak sesuai dengan standar yang terukur dan pasti, tidak menggunakan instrumen yang cukup, dan Tim Pemeriksa Kesehatan 
memberikan pendapat di luar kewenangannya.

Pertimbangan hukum Mahkamah Agung tersebut di atas, didasarkan atas pertimbangan hukum yang dinyatakan oleh Pengadilan Tinggi Tata Usaha Negara Medan Nomor: 03/G/PILKADA/2016/PT TUN-MDN, yang menyebutkan bahwa sesuai Pasal 46 ayat (5) Peraturan komisi Pemilihan Umum (PKPU) Nomor 9 Tahun 2016 tentang Perubahan Ketiga atas Peraturan Komisi Pemilihan Umum (PKPU) Nomor 9 Tahun 2015 tentang Pencalonan Pemilihan Gubernur dan Wakil Gubernur, Bupati dan Wakil Bupati dan/atau Walikota dan Wakil Walikota, menentukan bahwa hasil Pemeriksaan kesehatan bersifat final dan tidak dapat dilakukan pemeriksaan pembanding. ${ }^{17}$

Perlu ditegaskan di sini bahwa kewenangan KIP Aceh Tamiang dan kewenangan KPU Kota Pekanbaru yang akan diuraikan selanjutnya di bawah ini, khususnya dalam hal mengeluarkan keputusan terhadap calon peserta Pilkada yang tidak memenuhi syarat menjadi peserta Pilkada, diatur pada Pasal 67 ayat (2) Peraturan Komisi Pemilihan Umum Republik Indonesia (PKPU) Nomor 9

\footnotetext{
${ }^{17}$ Putusan Pengadilan Tinggi Tata Usaha Negara Medan Nomor: 03/G/PILKADA/ 2016/PT TUN-MDN, hlm. 28-29.
}

Tahun 2016 tentang Perubahan Ketiga atas Peraturan Komisi Pemilihan Umum Nomor 9 Tahun 2015 tentang Pencalonan Pemilihan Gubernur dan Wakil Gubernur, Bupati dan Wakil Bupati, dan/atau Walikota dan Wakil Walikota.

Selengkapnya, Pasal 67 Peraturan Komisi Pemilihan Umum Nomor 9 Tahun 2016 tersebut di atas, diuraikan sebagai berikut: Pertama, KPU Provinsi/KIP Aceh atau KPU/KIP Kabupaten/Kota menetapkan hasil verifikasi persyaratan pencalonan, persyaratan bakal calon, penetapan Pasangan Calon peserta Pemilihan pada rapat pleno dan menuangkan hasil verifikasi dalam Berita Acara Penetapan Pasangan Calon. Kedua, berdasarkan Berita Acara Penetapan tersebut, KPU Provinsi/KIP Aceh atau KPU/KIP Kabupaten/Kota menetapkan Pasangan Calon dengan Keputusan KPU Provinsi/KIP Aceh atau KPU/KIP Kabupaten/Kota. Ketiga, KPU Provinsi/KIP Aceh atau KPU/KIP Kabupaten/Kota mengumumkan hasil penetapan Pasangan Calon dalam rapat pleno terbuka di kantor KPU Provinsi/KIP Aceh atau KPU/KIP Kabupaten/Kota. ${ }^{18}$

\footnotetext{
${ }^{18}$ Pasal 67 ayat (1) sampai dengan Pasal 67 ayat (3) Peraturan Komisi Pemilihan Umum Republik Indonesia (PKPU) Nomor 9 Tahun
} 


\section{Penafsiran Hukum terhadap Pembatalan Calon Kepala Daerah dan Wakil Kepala Daerah yang Dinyatakan Tidak Lulus oleh Komisi Pemilihan Umum (KPU) Kota Pekanbaru}

Pada awalnya, mendiskualifikasi atau melakukan pengguguran bakal Paslon Dastrayani Bibra-Said Usman Abdullah disebabkan Said Usman Abdullah tidak memenuhi syarat kesehatan, yaitu dengan cara memberikan ceklist Tidak Memenuhi Syarat meski berdasarkan surat keterangan jawaban hasil pemeriksaan kemampuan rohani dan jasmani Nomor: 640/Yanmed/RSUD/360 yang

dikeluarkan oleh Rumah Sakit Umum Daerah (RSUD) Arifin Achmad, Said Usman Abdullah mampu menjalani rutinitas sehari-hari. Tegasnya, menurut KPU Kota Pekanbaru, Said Usman Abdullah tidak lolos kesehatan karena ditemukan adanya gangguan kesehatan berupa distabilitas, yang memiliki risiko yang dapat mengakibatkan ketidakmampuan untuk melaksanakan tugas dan kewajiban sebagai walikota/wakil walikota.

2016 tentang Perubahan Ketiga atas Peraturan Komisi Pemilihan Umum Nomor 9 Tahun 2015 tentang Pencalonan Pemilihan Gubernur dan Wakil Gubernur, Bupati dan Wakil Bupati, dan/atau Walikota dan Wakil Walikota.
Pada akhirnya, menindaklanjuti sengketa musyawarah Pilkada yang ditetapkan Panwaslu Pekanbaru, pada hari Senin, tanggal 7 November 2016, KPU Kota Pekanbaru, menetapkan Pasangan Calon (Paslon) H Dastrayani Bibra dan Said Usman Abdullah, menjadi Calon Wali Kota dan Wakil Wali Kota Pekanbaru, periode 2017-2022 dengan nomor urut 5 sesuai berita acara perubahan nomor keputusan KPU Kota Pekanbaru nomor 59/Kpts/KPU-Kota004.435265/X/2016 tentang penetapan pasangan calon Walikota dan Wakil Walikota 2017-2022. Dimana sebelumnya, sesuai rekomendasi Panwaslu Nomor: 01/LP/RI-11/10/2016 tentang penerusan pelanggaran administrasi pemilihan, menyatakan Said Usman Abdullah memenuhi syarat sebagai Bakal Calon Wakil Wali Kota Pekanbaru 2017-2022.

Salah satu hal yang menjadi pertimbangan mendasari putusan sidang sengketa tersebut di atas adalah putusan dari tim medis tidak menegaskan disabilitas yang menyebabkan berhalangan tetap terhadap Said Usman Abdullah. Pertimbangan selanjutnya adalah, menurut pendapat saksi ahli tata negara Maxasaii Indra, disabilitas tak menggugurkan hak kontitusi dipilih dan 
memilih. Pertimbangan selanjutnya adalah KPU tak memberi tahukan tanggapan rekomendasi dari Panwaslu sebelumnya, bahwa pasangan Dastrayani Bibra dan Said Usman Abdullah bisa mengikuti Pilkada. Sesuai dengan fakta persidangan dengan kesaksian para saksi yang dihadirkan dan bukti-bukti. Maka keputusan KPU yang menyatakan Said Usman Abdullah tidak memenuhi syarat karena disabilitas terbantahkan. Diambilnya keputusan tersebut, karena dalam pertimbangan Panwas, tidak ditemukan berdasarkan bukti kalimat yang tegas bahwa yang bersangkutan tidak memenuhi syarat. Oleh karena itu, antara keputusan dokter dan KPU yang menyatakan Said Usman Abdullah tidak memenuhi syarat, ada ruang penafsiran subjektivitas. Perlu ditegaskan kembali bahwa penyandang disabilitas memiliki hak yang sama untuk menjadi pejabat publik dipilih maupun dipilih.

\section{Berdasarkan Undang-Undang}

Nomor 8 Tahun 2016 tentang Penyandang Disabilitas, ditegaskan ketentuan bahwa Hak politik untuk Penyandang Disabilitas meliputi hak: memilih dan dipilih dalam jabatan publik; menyalurkan aspirasi politik baik tertulis maupun lisan; memilih partai politik dan/atau individu yang menjadi peserta dalam pemilihan umum; membentuk, menjadi anggota, dan/atau pengurus organisasi masyarakat dan/atau partai politik; membentuk dan bergabung dalam organisasi penyandang disabilitas dan untuk mewakili penyandang disabilitas pada tingkat lokal, nasional, dan internasional; berperan serta secara aktif dalam sistem pemilihan umum pada semua tahap dan/atau bagian penyelenggaraannya; memperoleh aksesibilitas pada sarana dan prasarana penyelenggaraan pemilihan umum, pemilihan gubernur, bupati/walikota, dan pemilihan kepala desa atau nama lain; dan memperoleh pendidikan politik. ${ }^{19}$

Berdasarkan Pasal 143 huruf d Undang-Undang Nomor 8 Tahun 2016 tentang Penyandang Disabilitas, ditegaskan bahwa setiap orang dilarang menghalang-halangi dan/atau melarang Penyandang Disabilitas untuk mendapatkan hak politik sebagaimana dimaksud dalam Pasal 13.

Sanksi hukum terhadap pelanggaran atas Pasal 143 huruf d diatur pada Pasal 145 Undang-Undang Nomor 8 Tahun 2016 tentang Penyandang Disabilitas, yang menyebutkan bahwa setiap orang yang menghalang-halangi dan/atau melarang Penyandang

\footnotetext{
${ }^{19}$ Pasal 13 Undang-Undang Nomor 8 Tahun 2016 tentang Penyandang Disabilitas.
} 
Disabilitas untuk mendapatkan hak manusia terhadap kelompok rentan, sebagaimana dimaksud dalam Pasal 143 khususnya penyandang disabilitas. ${ }^{20}$ dipidana dengan pidana penjara paling lama 2 (dua) tahun dan denda paling banyak Rp200.000.000,00 (dua ratus juta rupiah).

Selanjutnya, berdasarkan Pasal 75 Undang-Undang Nomor 8 Tahun 2016 tentang Penyandang Disabilitas, ditegaskan bahwa: Pemerintah dan Pemerintah Daerah wajib menjamin agar Penyandang Disabilitas dapat berpartisipasi secara efektif dan penuh dalam kehidupan politik dan publik secara langsung atau melalui perwakilan. Pemerintah dan Pemerintah Daerah wajib menjamin hak dan kesempatan bagi Penyandang Disabilitas untuk memilih dan dipilih.

Negara Republik Indonesia yang berdasarkan Pancasila dan UndangUndang Dasar Negara Republik Indonesia Tahun 1945 menghormati dan menjunjung tinggi harkat dan martabat manusia. Hak asasi manusia sebagai hak dasar yang secara kodrati melekat pada diri manusia bersifat universal, perlu dilindungi, dihormati, dan dipertahankan, sehingga pelindungan dan hak asasi

\section{Pengaturan Hukum yang Ideal terhadap Pembatalan Calon Kepala Daerah dan Wakil Kepala Daerah yang Tidak Memenuhi Persyaratan Kesehatan oleh KPUD}

Istilah lain untuk penafsiran hukum adalah interpretasi hukum. ${ }^{21}$ Penafsiran hukum adalah jembatan antara undang-undang yang statis, kaku dengan masa kini dan masa depan. ${ }^{22}$ Penafsiran terhadap konstitusi, sebagaimana penafsiran hukum pada umumnya, pasti dilakukan karena tidak seluruh ketentuan disusun dalam bentuk yang jelas dan tidak membuka penafsiran lagi. ${ }^{23}$

Kegiatan penafsiran merupakan aktivitas yang melekat dengan hukum dan ilmu hukum. Namun, selama ini studi ilmu hukum memberikan tempat yang

${ }^{20}$ Penjelasan Umum atas Undang-Undang Nomor 8 Tahun 2016 tentang Penyandang Disabilitas.

${ }^{21}$ Kurnia Dewi Anggraeny. 2017. Penafsiran Tindak Pidana Penodaan Agama dalam Perspektif Hukum, Volume 2, No. 1, hlm. 270.

22 Siti Malikhatun Badriyah. 2011. Penemuan Hukum (Rechtsvinding) dan Penciptaan Hukum (Rechtsschepping) oleh Hakim untuk Mewujudkan Keadilan, MMH, Jilid 40 No 3, hlm. 389.

${ }^{23}$ Muchamad Ali Safaat, Aan Eko Widiarto dan Fajar Laksono Suroso. 2017. Pola Penafsiran Konstitusi dalam Putusan Mahkamah Konstitusi Periode 2003 - 2008 dan 2009 - 2013, Jurnal Konstitusi, Volume 14, Nomor 2, hlm. 239. 
terbatas terhadap kegiatan penafsiran. ${ }^{24}$ Penafsiran hukum (dilihat dari bentuk hukumnya -- rechtsvorm) dapat bermakna luas, baik itu penafsiran terhadap hukum yang tertulis (geschreven recht) maupun hukum yang tidak tertulis (ongeschreven recht). ${ }^{25}$

Wewenang hak uji pada dasarnya menafsirkan hukum, judicial interpretations, penafsiran hukum. ${ }^{26}$ Penemuan hukum oleh hakim dalam putusan pengadilan sangatlah penting. Namun apabila penemuan tersebut didasarkan pada penafsiran hukum yang keliru, maka langkah tersebut tidaklah dapat dikatakan sebagai penemuan hukum dan justru akan berimplikasi pada munculnya kekecewaan masyarakat. ${ }^{27}$

$$
\text { Menurut Roger }
$$

Cotterrell, diperlukan pendalaman mengenai

24 Andi Desmon. 2018. Penafsiran Konstitusi dalam Bingkai Hukum Pancasila, Jurnal Cendekia Hukum: Vol. 3, No 2, hlm. 131.

25 Tim Penyusun Hukum Acara Mahkamah Konstitusi. 2010. Hukum Acara Mahkamah Konstitusi, Jakarta: Sekretariat Jenderal dan Kepaniteraan MKRI, hlm. 66.

26 Tim Penyusun Naskah Komprehensif Proses dan Hasil Perubahan UUD 1945. 2010. Naskah Komprehensif Perubahan Undang-Undang Dasar Negara Republik Indonesia Tahun 1945, Latar Belakang, Proses, dan Hasil Pembahasan, 1999-2002, Buku VI Kekuasaan Kehakiman, Jakarta: Sekretariat Jenderal dan Kepaniteraan Mahkamah Konstitusi, hlm. 293.

27 Melani. 2014. Disparitas Putusan Terkait Penafsiran Pasal 2 dan 3 UU Pemberantasan Tindak Pidana Korupsi: Kajian terhadap 13 Putusan Pengadilan Tipikor Bandung Tahun 2011-2012, Jurnal Yudisial Vol. 7 No. 2, 103116, hlm. 103. komunitas penafsiran, bagaimana mereka bekerja dan bagaimana kekuasaan memberikan suatu penafsiran yang mengikat sebagai hukum, dalam lingkup penafsiran hukum. ${ }^{28}$ Sebagai contoh, pendidikan jaksa dan hakim di Nederland berlangsung 6 (enam) tahun sesudah sarjana dan terpadu antara calon hakim dan jaksa, sehingga diperoleh kesatuan penafsiran hukum. ${ }^{29}$ Contoh lainnya adalah hukum progresif memberikan ruang kepada penegak hukum untuk berkreasi dan memberikan penafsiranpenafsiran yang progresif dalam penegakan hukum. ${ }^{30}$

Hukum dapat dipahami dengan memperhatikan dampak yang ditimbulkan terhadap hubungan antara berbagai pihak dalam kehidupan bermasyarakat dan bagaimana respon atau tanggapan berbagai pihak tersebut terhadap dampak dari penerapan hukum. Respon atau tanggapan dari para pihak yang memperoleh dampak positif adalah

28 Romli Atmasasmita. 2012. Tiga Paradigma Hukum dalam Pembangunan Nasional, Jurnal Hukum PRIORIS, Vol . 3 No. 1, h. 23. Lihat pula: Romli Atmasasmita. 2012. Teori Hukum Integratif: Rekonstruksi terhadap Teori Hukum Pembangunan dan Teori Hukum Progresif, Yogyakarta: Genta Publishing, hlm. 109.

${ }^{29}$ Oheo K. Haris. 2017. Telaah Yuridis Penerapan Sanksi di Bawah Minimum Khusus pada Perkara Pidana Khusus, Jurnal Ius Constituendum Volume 2 Nomor 2, hlm. 253.

30 Mahrus Ali (Editor). 2013. Membumikan Hukum Progresif, Yogyakarta: Aswaja Pressindo, hlm. 34. 
tindakan mendukung (pro) penerapan hukum dan oleh karena itu para pihak tersebut akan berupaya meningkatkan dampak positif tersebut. ${ }^{31}$

Sejak hukum membuat tradisi untuk dituliskan (written law), maka pembacaan terhadap teks hukum menjadi masalah yang penting. Sejak pembacaan teks menjadi penting, maka penafsiran terhadap teks hukum tak dapat dihindarkan. Bahkan tidak berlebihan apabila dikatakan, penafsiran hukum merupakan jantung hukum. Hampir tidak mungkin hukum bisa dijalankan tanpa membuka pintu bagi penafsiran. ${ }^{32}$ Oleh karena itu, penafsiran hukum membutuhkan keahlian khusus mencakup seluruh landasan normatif, sosiologis, yuridis, filosofis, dan empirisme, dalam menelusuri keterkaitan aturan hukum yang satu dengan yang lain. ${ }^{33}$

Bahasa dan hukum mempunyai hubungan yang erat sekali. Oleh karena itu, pembuat undang-undang yang ingin menyatakan kehendaknya secara jelas, harus memilih kata-kata yang tepat.

31 Tommy Hendra Purwaka. 2015. Beberapa Pendekatan untuk Memahami Hukum (Several Approaches for Understanding the Law), Jurnal Hukum dan Peradilan, Volume 4, Nomor 3, 519-536, hlm. 531.

32 Satjipto Rahardjo. 2009. Hukum Progresif, Yogyakarta: Gentha Publishing, hlm. 116.

${ }^{33}$ H.F. Abraham Amos. 2011. Legal Opinion: Aktualisasi Teoretis \& Empirisme, Jakarta: Rajawali Pers, hlm. 43.
Peraturan hukum hendaknya dirumuskan dengan singkat, jelas dan tidak mengandung pengertian yang beraneka ragam. Akan tetapi, pembuat undangundang tidak selamanya dapat melakukan semua ini. ${ }^{34}$

Berdasarkan uraian di atas dan uraian pada sub bab sebelumnya, penulis berpendapat bahwa pengaturan hukum yang ideal terhadap pembatalan calon kepala daerah dan wakil kepala daerah yang tidak memenuhi persyaratan kesehatan oleh KPUD, adalah sebagai berikut: Pertama, pembentuk undangundang harus menegaskan bahwa Tim Pemeriksa Kesehatan hanya berwenang untuk menyatakan ada atau tidaknya disabilitas serta sejauh mana disabilitas tersebut, bukan menyatakan calon peserta Pilkada memenuhi syarat atau tidak memenuhi syarat menjadi peserta Pilkada sehingga tim tersebut tidak memberikan kesimpulan di luar kewenangannya. Kedua, pembentuk undang-undang harus menegaskan bahwa penyandang disabilitas tidak terhalang untuk mendapatkan hak politik seperti memilih dan dipilih dalam jabatan publik; menyalurkan aspirasi politik baik tertulis maupun lisan; memilih partai politik

\footnotetext{
${ }^{34}$ Riduan Syahrani. 2013. Rangkuman Inti Sari Ilmu Hukum, Bandung: Citra Aditya Bakti, hlm. 62.
} 
dan/atau individu yang menjadi peserta dalam pemilihan umum; membentuk, menjadi anggota, dan/atau pengurus organisasi masyarakat dan/atau partai politik; membentuk dan bergabung dalam organisasi penyandang disabilitas dan untuk mewakili penyandang disabilitas pada tingkat lokal, nasional, dan internasional; berperan serta secara aktif dalam sistem pemilihan umum pada semua tahap dan/atau bagian penyelenggaraannya; memperoleh aksesibilitas pada sarana dan prasarana penyelenggaraan pemilihan umum, pemilihan gubernur, bupati/walikota, dan pemilihan kepala desa atau nama lain; dan memperoleh pendidikan politik.

\section{KESIMPULAN}

1. Penafsiran hukum terhadap pembatalan calon kepala daerah dan wakil kepala daerah yang tidak memenuhi persyaratan kesehatan oleh KPUD adalah sebagai berikut:

a. Komisi Independen Pemilihan (KIP) Aceh Tamiang menafsirkan Tim Pemeriksa Kesehatan berwenang untuk menyatakan calon peserta Pilkada memenuhi syarat atau tidak memenuhi syarat menjadi peserta Pilkada. Sedangkan menurut tafsiran Mahkamah Agung, tim tersebut hanya berwenang menyatakan ada atau tidaknya disabilitas serta sejauh mana disabilitas tersebut, bukan menyatakan calon peserta Pilkada memenuhi syarat atau tidak memenuhi syarat menjadi peserta Pilkada sehingga tim tersebut memberikan kesimpulan di luar kewenangannya.

b. Komisi Pemilihan Umum (KPU) Kota Pekanbaru menafsirkan bahwa penyandang disabilitas terhalang untuk mendapatkan hak politik. Sedangkan menurut Panitia Pengawas Pemilihan (Panwas) Kota Pekanbaru, penyandang disabilitas tidak terhalang untuk mendapatkan hak politik.

2. Pengaturan hukum yang ideal terhadap pembatalan calon kepala daerah dan wakil kepala daerah yang tidak memenuhi persyaratan kesehatan oleh KPUD adalah:

a. Pembentuk undang-undang tegas menyatakan bahwa Tim Pemeriksa Kesehatan hanya berwenang menyatakan ada atau tidaknya disabilitas, bukan menyatakan calon peserta 
Pilkada memenuhi syarat atau tidak memenuhi syarat menjadi peserta pemilihan kepala daerah.

b. Pembentuk undang-undang harus menegaskan bahwa penyandang disabilitas tidak terhalang untuk mendapatkan hak politik seperti memilih dan dipilih dalam jabatan publik; menyalurkan aspirasi politik baik tertulis maupun lisan; memilih partai politik dan/atau individu yang menjadi peserta dalam pemilihan umum; membentuk, menjadi anggota, dan/atau pengurus organisasi masyarakat dan/atau partai politik; membentuk dan bergabung dalam organisasi penyandang disabilitas dan untuk mewakili penyandang disabilitas pada tingkat lokal, nasional, dan internasional; berperan serta secara aktif dalam sistem pemilihan umum pada semua tahap dan/atau bagian penyelenggaraannya;

memperoleh aksesibilitas pada sarana dan prasarana penyelenggaraan pemilihan umum, pemilihan gubernur, bupati/walikota, dan pemilihan kepala desa atau nama lain; dan memperoleh pendidikan politik.

\section{REFERENSI}

Abdullah, Rozali. 2011. Pelaksanaan Otonomi Luas dengan Pemilihan Kepala Daerah Secara Langsung, Jakarta: RajaGrafindo Persada.

Ali, Mahrus (Editor). 2013. Membumikan Hukum Progresif, Yogyakarta: Aswaja Pressindo.

Amos, H.F. Abraham. 2011. Legal Opinion: Aktualisasi Teoretis \& Empirisme, Jakarta: Rajawali Pers.

Anggraeny, Kurnia Dewi. 2017. Penafsiran Tindak Pidana Penodaan Agama dalam Perspektif Hukum, Volume 2, No. 1 .

Artina, Dessy. 2016. Keterwakilan Politik Perempuan di Beberapa Negara, Yogyakarta: Best Publisher.

Asshiddiqie, Jimly. 2010. Perkembangan \& Konsolidasi Lembaga Negara Pasca Reformasi, Jakarta: Sinar Grafika.

Atmasasmita, Romli. 2012. Teori Hukum Integratif: Rekonstruksi terhadap Teori Hukum Pembangunan dan Teori Hukum 
Progresif, Yogyakarta: Genta

Publishing.

Atmasasmita, Romli. 2012. Tiga

Pembangunan Nasional, Jurnal

Hukum PRIORIS, Vol. 3 No. 1.

Badriyah, Siti Malikhatun. 2011.

Penemuan

Hukum

(Rechtsvinding) dan Penciptaan

Hukum (Rechtsschepping) oleh

Hakim untuk Mewujudkan

Keadilan, MMH, Jilid 40 No 3.

Desmon, Andi. 2018. Penafsiran

Konstitusi dalam Bingkai

Hukum Pancasila, Jurnal

Cendekia Hukum: Vol. 3, No 2.

Haris, Oheo K. 2017. Telaah Yuridis

Penerapan Sanksi di Bawah

Minimum Khusus pada Perkara

Pidana Khusus, Jurnal Ius

Constituendum Volume 2 Nomor

2.

Hoesein, Zainal Arifin. 2013. Judicial

Review di Mahkamah Agung

Republik Indonesia: Tiga

Dekade Pengujian Peraturan

Perundang-undangan, Jakarta:

Rajawali Pers.

Kaho, Josef Riwu. 2010. Prospek

Otonomi Daerah di Negara

Republik Indonesia (Identifikasi

Faktor-faktor

yang
Mempengaruhi

Penyelenggaraan

Otonomi

Daerah), Jakarta: Rajawali Pers.

Martitah. 2013. Dari Negative Legislature, Mahkamah

Konstitusi, ke Positive

Legislature?, Jakarta: Konstitusi Pers.

Melani. 2014. Disparitas Putusan Terkait Penafsiran Pasal 2 dan 3 UU Pemberantasan Tindak Pidana Korupsi: Kajian terhadap 13 Putusan Pengadilan Tipikor Bandung Tahun 2011-2012, Jurnal Yudisial Vol. 7 No. 2, 103-116.

Mohamad Yoenus, Panwaslu Pekanbaru Menangkan Gugatan Pasangan Destrayani-Said Usman, http://www.tribunnews.com/regi onal/2016/11/06/panwaslupekan barumenangkangu gatan pasangandestrayanisaidusman, diakses tanggal 17 Januari 2018.

Nasution, Faisal Akbar. 2009. Pemerintahan Daerah dan Sumber-sumber Pendapatan Asli Daerah, Jakarta: Sofmedia.

Ndraha, Taliziduhu. 2011. Kybernology: Ilmu Pemerintahan Baru 1, Jakarta: Rineka Cipta. 
Peraturan Komisi Pemilihan Umum Safaat, Muchamad Ali., Widiarto, Aan Republik Indonesia (PKPU) Eko., dan Suroso, Fajar Laksono. Nomor 9 Tahun 2016 tentang 2017. Pola Penafsiran Konstitusi Perubahan Ketiga atas Peraturan dalam Putusan Mahkamah Komisi Pemilihan Umum Nomor Konstitusi Periode 2003 - 2008 9 Tahun 2015 tentang dan 2009 - 2013, Jurnal Pencalonan Pemilihan Gubernur Konstitusi, Volume 14, Nomor 2. dan Wakil Gubernur, Bupati dan Wakil Bupati, dan/atau Walikota dan Wakil Walikota.

Citra Aditya Bakti.

Purwaka, Tommy Hendra. 2015. Tim Penyusun Hukum Acara Mahkamah Beberapa Pendekatan untuk Memahami Hukum (Several Approaches for Understanding the Law), Jurnal Hukum dan Peradilan, Volume 4, Nomor 3, 519-536.

Putusan Mahkamah Agung Nomor 572 K/TUN/PILKADA/2016.

Konstitusi. 2010. Hukum Acara Mahkamah Konstitusi, Jakarta: Sekretariat Jenderal dan Kepaniteraan MKRI.

Tim Penyusun Naskah Komprehensif Proses dan Hasil Perubahan UUD 1945. 2010. Naskah Komprehensif Perubahan

Putusan Pengadilan Tinggi Tata Usaha Negara Medan Nomor: Undang-Undang Dasar Negara 03/G/PILKADA/ 2016/PT TUNMDN.

Qanun Aceh Nomor 5 Tahun 2012 tentang Pemilihan Gubernur/Wakil Gubernur, Bupati/Wakil Bupati dan Walikota/Wakil Walikota. Republik Indonesia Tahun 1945, Latar Belakang, Proses, dan Hasil Pembahasan, 1999-2002, Buku VI Kekuasaan Kehakiman, Jakarta: Sekretariat Jenderal dan Kepaniteraan Mahkamah Konstitusi.

Undang-Undang Nomor 10 Tahun 2016 tentang Perubahan Kedua atas Undang-Undang Nomor 1 Tahun Progresif, Yogyakarta: Gentha 2015 tentang Penetapan Publishing. 
Undang-Undang Nomor 1 Tahun

2014 tentang Pemilihan

Gubernur, Bupati, dan Walikota

Menjadi Undang-Undang.

Undang-Undang Nomor 11 Tahun 2006

tentang Pemerintahan Aceh.

Undang-Undang Nomor 8 Tahun 2016

tentang Penyandang Disabilitas. 


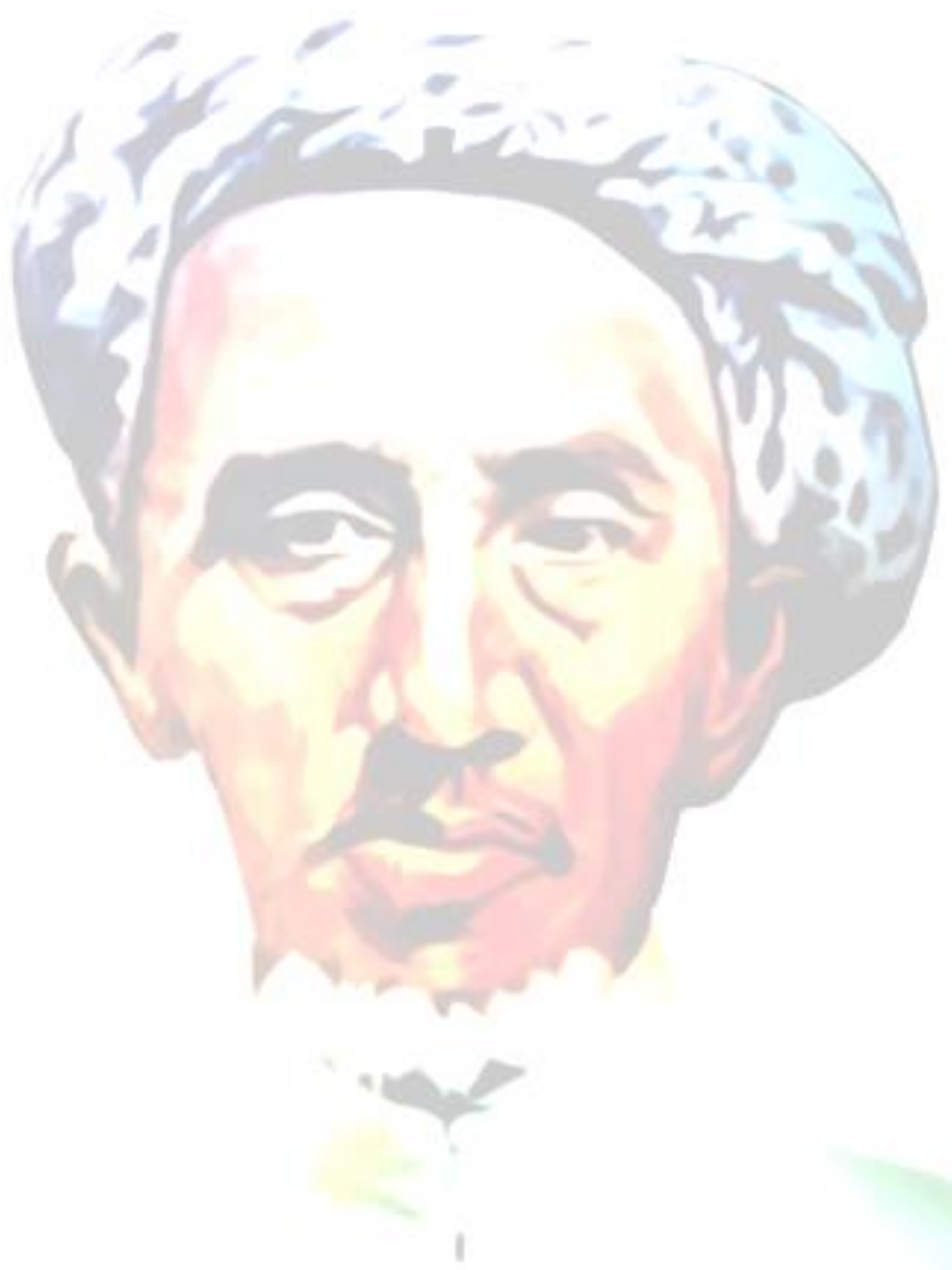

